\title{
Toys Are Good for Us: Why We Should Embrace the Historical Integration of Children's Literature, Material Culture, and Play
}

\section{Citation}

Bernstein, Robin. 2013. “Toys Are Good for Us: Why We Should Embrace the Historical Integration of Children's Literature, Material Culture, and Play." Children's Literature Association Quarterly 38, no. 4: 458-463.

\section{Published Version}

doi:10.1353/chq.2013.0051

\section{Permanent link}

http://nrs.harvard.edu/urn-3:HUL.InstRepos:12841968

\section{Terms of Use}

This article was downloaded from Harvard University's DASH repository, and is made available under the terms and conditions applicable to Other Posted Material, as set forth at http:// nrs.harvard.edu/urn-3:HUL.InstRepos:dash.current.terms-of-use\#LAA

\section{Share Your Story}

The Harvard community has made this article openly available.

Please share how this access benefits you. Submit a story.

\section{Accessibility}




\section{PROJECT MUSE}

\section{Toys Are Good for Us: Why We Should Embrace the}

Historical Integration of Children's Literature, Material Culture, and Play Robin Bernstein

Children's Literature Association Quarterly, Volume 38, Number 4, Winter 2013, pp. 458-463 (Article)

Published by The Johns Hopkins University Press DOI: 10.1353/chq.2013.0051

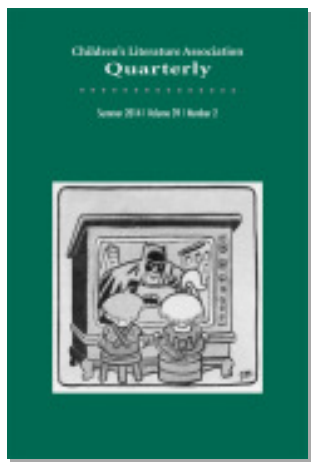

$\Rightarrow$ For additional information about this article http://muse.jhu.edu/journals/chq/summary/v038/38.4.bernstein.html 


\title{
Toys Are Good for Us: Why We Should Embrace the Historical Integration of Children's Literature, Material Culture, and Play
}

\author{
Robin Bernstein
}

$\mathbf{M}$ any histories of children's literature date our field to 1744, when British publisher and book vender John Newbery conceived of children as a market, and writing for children as a distinct category of literature. He launched the genre of children's literature when he sold A Little Pretty Pocket-Book ensemble with balls and pincushions. For these innovations, Newbery became known as the "father of children's literature." This tale is not the field's only origin story; some scholars trace the genre through folktales or fables, for example. Alternative narratives, however, must still reckon with Newbery. For instance, Seth Lerer opens Children's Literature: A Reader's History from Aesop to Harry Potter by hailing Newbery, if only to leapfrog over him: "Long before John Newbery established the first press devoted to children's books, stories were told and written for the young" (1). Even when the paternity of children's literature is disputed, then, Newbery is still in the court. The Newbery Medal, awarded annually by the Association for Library Service to Children, a division of the American Library Association, honors "the author of the most distinguished contribution to American literature for children"- and thus reasserts Newbery's foundational place in children's literature (ALA n. pag.).

This familiar origin story deserves closer attention, particularly in regard to two extraordinary aspects. First, this story identifies the beginning of children's literature through a then-innovative relationship to material culture. We tend to understand the commercialization of children's literature as a relatively recent and noxious practice, spanning the sale of everything from Elsie Dinsmore paper dolls in the nineteenth century through today's avalanche of junk ranging from Cat in the Hat stickers to Harry Potter vibrating broomsticks to

\footnotetext{
Robin Bernstein is Professor of African and African American Studies and of Studies in Women, Gender, and Sexuality at Harvard University. She is the author of Racial Innocence: Performing American Childhood from Slavery to Civil Rights (New York UP, 2011), which has won several awards, including the Book Award from the Children's Literature Association, the Grace Abbott Best Book Award from the Society for the History of Children and Youth, and the IRSCL Award from the International Research Society for Children's Literature.
} 
entire book series, such as American Girl, that are designed to integrate fully with a universe of expensive commodities. We often critique-rightly-the reduction of imaginative worlds to mass-produced commodities. But if we elevate literature by denigrating attendant nonbook commodities, we forget that the union of literature and material culture has defined children's literature since 1744 . We forget, too, that even aside from the story of Newbery and his pretty little books, the entanglement of children's literature and material culture has broadened and intensified over the past two and a half centuries. And thus we ignore, or even reject, exactly what sets children's literature apart from other genres.

The second extraordinary aspect of the familiar story of John Newbery is that in this origin story, children's literature was defined, from the start, in relationship to children's play. The bulk of A Little Pretty Pocket-Book consists of a catalog of games, many of which involve playthings such as kites, shuttlecocks, and balls. Newbery's introduction instructed boys not to play with the black-and-red ball they received alongside the book, but instead to use the toy for moral instruction: "your Nurfe may hang up the Ball by the String to it, and for every good Action you do a Pin fhall be ftuck on the Red Side, and for every bad Action a Pin fhall be ftuck on the Black Side" (65). ${ }^{2}$ This brief instruction weighed, however, against page after page of descriptions of children playing with balls: cricket balls and base-balls, stool-balls and trap-balls, and on and on. The book, Newbery specified in his subtitle, was "Intended for the Instruction and Amusement" of children — and the material culture that attended the book offered precisely the same possibilities.

My point is not that play and material culture are rich subjects for study (although, of course, they are). Rather, I propose that we take seriously this story of the origin of children's literature as a genre, and that we strategically maximize upon the implications of this narrative-even as we acknowledge alternative origin stories. ${ }^{3}$ The history of children's literature exists not in opposition to, but in integration with, the histories of children's material culture and children's play. This manifesto calls for us to reconceive the field of children's literature through this integration. If we foreground the triangulation of children's literature, material culture, and play, our field stands to gain three substantial benefits.

Before I describe those benefits, I want to make one thing clear: I am not calling for the field of children's literature to transform into a branch of cultural studies. I am not saying that we should abandon studies of children's literature that choose not to attend to toys or play. The point I'm making, instead, is this: the historical relationship to material culture and play endows the field of children's literature with powers and possibilities, and we should take advantage of these opportunities.

The first benefit we stand to gain is a clearer vision of how children's literature actually functions in the everyday lives of children. I am not calling for us to integrate children's literature with material culture and play, but instead to stop 
erecting arbitrary barriers between children's literature and play with material culture. Such boundaries make sense for most other genres of literature, but in our case they are counterfactual and counterhistorical. For two and a half centuries, children's literature has persistently and increasingly triangulated with material culture and the actions of playing. Even when an individual children's book has no material tie-ins, the material commodity still exists as potential—now more so than ever. By acknowledging and foregrounding these connections, we align our understanding of children's literature with historical reality.

This entanglement with materiality and action makes children's literature nearly unique among literary genres. I can think of only two other genres that fundamentally integrate with the material world and bodily actions. The first of these is drama, which integrates with material props to be used and actions to be performed onstage. The other genre that fundamentally integrates with materiality and physical actions is pornography, which exists to alter the state of the material body and to facilitate masturbation or other sexual behavior. Children's literature, drama, and porn: this is the sort of unexpected and provocative constellation that can emerge when we stop ahistorically walling off children's literature from material culture and actions. ${ }^{4}$

Second, this approach can mitigate or even correct an existing problem within our field. My previous point that children's literature is nearly unique in that it is defined by a historical relationship to material culture and play butts up against an existing argument about what makes children's literature unique: it is the only genre written by one group (adults) for another group (children). This is the position forwarded by Jacqueline Rose and others, including Perry Nodelman. ${ }^{5}$ I have argued previously, and I would like to reassert here, that this claim has led to an overestimation of adult power and an underestimation of children's agency (see Bernstein, "Children's Books" 160-69). A reevaluation of children's literature as a genre defined in relation to play and material culture can mitigate this problem-indeed, it can reverse it. When we view children's literature as something that adults produce and children consume, of course we see power emanating from the top down. But if we understand children's literature as persistently integrating with material culture and play, a very different picture emerges. We see adults producing children's literature and children's material culture, and we see children playing with and through both. Children's play is simultaneously compliant and unruly. It is not simplistically resistant; rather, it is creative, symptomatic, anarchic, ritualistic, reiterative, and most of all, culturally productive. Children receive mass-produced material culture, but they adapt it: they chop hair off dolls, apply stickers to toy trucks, endow plastic blocks with names and personalities. They play in ways that are socially sanctioned and they play otherwise. When we remember that John Newbery inaugurated children's literature by linking a book to toys and play, and when we view that linkage not as a distortion but as the definition of our 
genre, it becomes impossible to maintain a unidirectional, top-down view of power in children's literature.

Third and finally, this approach renews the relevance and urgency of the study of children's literature across the university. Material culture and/or play are already well-established fields of study in departments of history, economics, anthropology, archeology, and sociology. As we integrate the study of children's literature with the study of material culture and play-or rather, as we stop denying the historical integration of these three factors-our scholarship becomes profoundly useful to the goals of these departments. In other words, we can position children's literature and childhood studies as exciting and hotly relevant sources of insight and evidence for any department that already cares about play or material culture. Furthermore, because the triangulation of children's literature, material culture, and play integrates historical, literary, material, and performative evidence, the approach I am advocating could potentially make children's literature central to interdisciplinary fields including American studies, critical race studies, ethnic studies, media studies, gender studies, performance studies, and cultural studies. Children's literature can and should be to these fields today what punk culture was to the Birmingham School thirty years ago: a fresh and unexpected site of analysis where scholars in established fields can shake things up, renew their creativity, and develop new theoretical paradigms about issues such as subversion, resistance, agency, culture, and counterculture. Our field need not and should not become cultural studies, American studies, or even history. Instead, we should honor material culture and play as connections between our field and other disciplines and interdisciplines in the humanities and social sciences. Material culture and play provide a means by which to hinge our field to others. This hinge makes the use-value and vitality of our scholarship visible to them.

For too long, our field has tried to establish itself within and across the university by making the case that children's literature is complex, interesting, and important. This argument appeals to us because it is undoubtedly correct. In other words, the truth of the argument makes it feel strong. It is, however, ultimately a weak argument because anything, if examined creatively and rigorously, emerges as complex, interesting, and important. To construct a stronger argument, our field should take a cue from feminism. Feminist scholars have argued that women are people, and that therefore any department that aims to study people, but that in fact studies only men, is inadequate by its own standards. We need to make the parallel case for children. Children exist and are numerous in all human societies. Indeed, in many parts of the world and in many periods of history, children have outnumbered adults. In 2011, for example, people under the age of eighteen outnumbered those over eighteen in Afghanistan, Chad, Niger, Zambia, and many other countries, particularly on the African continent (UNICEF n. pag.). Children outnumbered adults in Colonial America, Bermuda, and many other areas of the world prior to $1800 .^{6}$ 
An integrated view of children's literature, material culture, and play requires us to see children in multiple dimensions - that is, as people (my point here is deeply resonant with that of Marah Gubar, who in her own manifesto in this Forum calls for a "kinship model" that understands children and adults as "separated by differences of degree, not of kind" (454). Thus the approach I am advocating facilitates a new argument: Every department in the humanities and social sciences needs to study children—not because children are interesting and important, but because they are people.

Because children are people, every department that studies people needs a specialist in childhood. Notice that I am not intoning what departments "should" do but am instead pointing out what they need to do in order to fulfill their own intellectual missions. Every history department needs a historian of childhood. Every interdisciplinary department-African American studies, ethnic studies, gender studies, American studies—needs an interdisciplinary scholar of childhood studies. Every music department needs a specialist in children's music. Every theater department needs scholars and practitioners of children's theater. Let us imagine a world in which every department in the humanities and the social sciences understands itself to be incomplete without someone who studies children and childhood—and therefore every department that studies literature needs a children's literature scholar. ${ }^{7}$ These are the payoffs of embracing the historical reality of children's agential integration of literature with toys through play.

\section{Notes}

1. On Newbery as the founder of the field of children's literature or children's publishing, see, for example, Clark and Higgonet; Noblett; Kidd; Granahan; and Nodelman.

2. Identical instructions attended the black-and-red pincushion that girls received with the book.

3. Even if a shocking archival discovery proved that Newbery never existed-that all evidence of his work was in fact the product of an elaborate hoax, and that therefore the Newbery origin story is pure fiction-my argument would not change. My point is not that Newbery defines children's literature, but rather that a) children's literature historically has integrated with toys and play, and that this has become increasingly true over the past century; and b) the story of Newbery as the "father" of children's literature has use-value to our field, and this use-value can be tapped strategically.

4. One could, of course, argue that all written texts integrate material culture and bodily actions because all written texts involve some sort of material medium (manuscript pages, book, newspaper, computer screen, etc.) and embodied processes including writing and reading. This argument is certainly correct; it is one that I make in Racial Innocence: Performing American Childhood from Slavery to Civil Rights (see esp. 74-81 and 105-12). My point is that the genres of children's literature, drama, and pornography fundamentally exist in relation to materiality beyond that of the text itself.

5. Children's Literature Association Quarterly devoted its full Fall 2010 issue to revisiting Rose's argument. It includes essays by David Rudd, Anthony Pavlik, Perry Nodelman, Beatrice Turner, Gabrielle Owen, and Alison Waller. 
6. See, for example, Jarvis; Anzilotti; and Bell.

7. Sara L. Schwebel pointed out to me that the shift I am calling for is already well underway in universities that have departments or schools of education; such institutions often include scholars of childhood across the curriculum. In this way, they offer a model that the rest of the academy would do well to imitate.

\section{Works Cited}

American Library Association, Association for Library Service to Children division. Newbery Medal Home Page. 25 July 2013. <http://www.ala.org/alsc/awardsgrants/ bookmedia/newberymedal/newberymedal $>$.

Anzilotti, Cara. In the Affairs of the World: Women, Patriarchy, and Power in Colonial South Carolina. Westport, CT: Greenwood Publishing Group, 2002. 35.

Bell, J. L. "From Saucy Boys to Sons of Liberty: Politicizing Youth in Pre-Revolutionary Boston." Children in Colonial America. Ed. James Marten. New York: New York UP, 2007). 204-05.

Bernstein, Robin. "Children's Books, Dolls, and the Performance of Race; or, The Possibility of Children's Literature." PMLA 26.1 (2011): 160-69.

- Racial Innocence: Performing American Childhood from Slavery to Civil Rights. New York: New York UP, 2011.

Clark, Beverly Lyon, and Margaret R. Higonnet, eds. Girls, Boys, Books, Toys: Gender in Children's Literature and Culture. Baltimore: Johns Hopkins UP, 1999. 1.

Granahan, Shirley. John Newbery: Father of Children's Literature. Edina, MN: Abdo Publishing Company, 2010.

Jarvis, Michael J. In the Eyes of All Trade: Bermuda, Bermudians, and the Maritime Atlantic World, 1680-1783. Chapel Hill: U of North Carolina P, 2010. 266.

Kidd, Kenneth B. “Prizing Children's Literature: The Case of Newbery Gold.” Children's Literature 35 (2007): 171.

Lerer, Seth. Children's Literature: A Reader's History from Aesop to Harry Potter. Baltimore: Johns Hopkins UP, 2008. 1.

Newbery, John. A Little Pretty Pocket-Book: A Facsimile with an Introductory Essay and Bibliography by M. F. Thwaite. London: Oxford UP, 1966. 65.

Noblett, William. "John Newbery: Publisher Extraordinary." Only Connect: Readings on Children's Literature. Ed. Sheila Egoff, G. T. Stubbs, and L. F. Ashley. Toronto: Oxford UP, 1980. 28-38.

Nodelman, Perry. The Hidden Adult: Defining Children's Literature. Baltimore: Johns Hopkins UP, 2008. 250.

Rose, Jacqueline. The Case of Peter Pan; or, The Impossibility of Children's Fiction. Philadelphia: U of Pennsylvania P, 1984.

UNICEF. “ChildInfo: Monitoring the Situation of Children and Women." <http://www. childinfo.org/>. 